\title{
Supporting Teachers to Implement Inclusive Education in the Kwaluseni District, Swaziland
}

\author{
Maseko, Nonhlanhla Desiree
}

maseknd@unisa.ac.za

\author{
Sisana Susan Fakudze \\ Department of Inclusive Education, College of Education, University of South Africa (UNISA), \\ PO Box 392 Pretoria 0003 \\ sisanaf@gmail.com
}

\section{Doi:10.5901/mjss.2014.v5n27p513}

\begin{abstract}
This paper sought to explore ways in which teachers can be supported to implement inclusive education at a primary school in the Kwaluseni district of Swaziland. The government of Swaziland introduced Free Primary Education ( F.P.E) also called mainstreaming. As per governments order, parents brought their learners for grade 1 and that was in 2010 January. That marked the beginning of the problem as teachers were not used to teaching disadvantaged learners in their classes but believed that such learners have to be transferred to specials schools of which the country only has four. The study is a case study using a qualitative approach. Purposive sampling was used in choosing the sample. The key informants were teachers from Kwaluseni. For data collection a designed interview with semi structured and open ended questions was used. Data was analysed using codes and there was a search for patterns of thinking or behaviour, words or phrases that appeared with regularity was the coding categories. A report was then written based on the findings. Then recommendations were stated.
\end{abstract}

Keywords: Special educational needs, special schools, mainstream, integration and ordinary local schools.

\section{Introduction}

The kingdom of Swaziland's national response to psychosocial needs of children (2010:25) defines inclusive education as a policy approach that includes and meets the needs of all the learners. It enables schools to serve and welcome all learners and it is rooted in the basic human right to education. Furthermore, the Swazi national children's policy (2009:25) stipulates that compulsory inclusive basic education be provided free for all children in the country, irrespective of gender, age, life circumstances, health, and disability, stage of development, capacity to learn or financial circumstances.

The Constitution of the kingdom of Swaziland (2005) states that every Swazi child within three years of the commencement of this Constitution has the right to free education in public schools at least up to the end of primary school, beginning with the first grade.

Currently, the Government of Swaziland has well-structured institutions of higher learning with teacher training institutions as the most dominant. In addition to the University of Swaziland there are four institutions for teacher training. From the Deputy Prime Minister's office (2010:39), The National Response to Psychosocial Needs of Children states that the syllabus used at teacher training institutions has to be revised to incorporate issues of children's rights, special needs, as well as orphans and vulnerable children. In these institutions, teachers are currently trained to teach different subjects found in most of the schools, for instance English language, SiSwati, Mathematics and Biology, despite the education sector's policy mission being to ensure equitable access to inclusive, lifelong quality education and training for all Swazi citizens through sustained implementation and resourcing of comprehensive education and training. Upon completion, these teachers are then placed in the different schools around the country, both primary and high schools, rural and urban. Their training is such that they have a syllabus that guides them and must be covered within a year. They have a special responsibility to implement values and ensure that all learners with or without disabilities pursue their learning potential to the fullest. It is the role of every good teacher to meet the needs of all learners as one of the objectives in the Deputy Prime Minister's office (2010:26) the national response to psychosocial needs of children is to assure every learner in Swaziland meaningful participation and achievement in the teaching and learning process. However, those without barriers to learning normally fall in the bracket of fast learners, impressing the teachers and thus receiving 
favourable discrimination.

Teachers have to address the needs of all these learners, which calls for commitment and the use of appropriate teaching methods. If teachers are not motivated to support inclusive education they will find it difficult, hence the temptation to ignore the learners' needs and focus on the syllabus. Diversity demands teachers to be ready to address barriers to learning, something that they cannot do if they lack knowledge of inclusive education. At times they may know about it but support from the relevant stakeholders plays a crucial role.

Swaziland has limited opportunities for self-development, such as part-time further studies, and has limited visits by school inspectors and other cadres. Recently, the country's current primary and secondary curricula have mainstreamed the study of preventing HIVIAIDS, along with other life skills. Teachers were trained and had knowledge and awareness of the epidemic but not of inclusive education. Hence, they (teachers ) still use terms such as 'fast learners' and 'slow learners', the former being those who easily grasp new concepts and complete given tasks easier and quicker, the latter being those who take time to grasp. Most of these learners are accommodated in the mainstream schools, and labelled so that teachers can capitalise on the weaknesses whilst ignoring the strengths.

\section{Literaturen Review}

\subsection{Strategies for implementing Inclusive}

Piuik, Bentel \& Jose (2010: 65) state that the examination of school climates and cultures for promoting inclusive efforts within schools should include those elements considered as appropriate models for inclusive practice. Successful inclusive school climate depends on the attitudes and actions of the principal, a supportive school community and shared values and language. Teachers are observed to be integral to the implementation of inclusive education, and research indicates that teachers are the key to the success of inclusionary programmes (Cant, 1994:54). Teacher training in these areas improves participation and accommodation efforts as well as teacher confidence. Smith (2010:34) states that teachers, administrators and other stakeholders need to adjust structures and school curricula to make them more favourable for special needs children"s learning process. In addition, teachers need to desist from stereotyping as this stems from ignorance and impedes the process of inclusion. Whilst teachers may try their best to implement some of the strategies, if they lack support from the administrators and other stakeholders then can achieve little.

There are certain skills and types of knowledge that will help teachers teach children with special needs (Reynolds \& Fletcher, 2007:346). Motshekga (2010:2) argues that without a new mind set and the right support systems in place, inclusive education will remain no more than an ideal. Thus, one of the responsibilities of the DoE is to successfully change the character of schools and ensure the implementation of inclusive education. Amongst a number of policies introduced to increase access to education was the introduction of free primary education (FPE) in 2010, from Grades 1 to 5 and, subsequently to be rolled out to all primary school grades by 2015 as an "education for all" plan of action. Policies on inclusive education in Swaziland are however generally still at the draft stage, with the 2008 draft inclusive Education policy being the latest. The Constitution of the kingdom of Swaziland (2005) clearly indicates that all children have a right to education, but from the evidence presented above it will take time before the Ministry of Education devises strategies for effective implementation of inclusive education. I argue that the absence of policies is delaying the implementation and, in the process, many learners are classified as „underachievers" in school.

Opertti (2009) argues that inclusion involves changes and modification in content, approaches and strategies. Results from a study conducted by Engelbrecht ,Oswald,Swart \& Eloff (2003:306) confirmed lack of support services and indicated that teachers were in need of effective non-stop support service in an inclusive classroom and school. Cameron (2004) recommends that university-based teacher education programme insist that all teacher candidates meet basic competency standards on inclusive practices in order to graduate. They can thus fit into inclusive classrooms. Reid (2010) states that a fully inclusive educational setting necessitates planning, trained teachers and other support staff. It can be argued therefore that quality and definition of service delivery is vital to the training and skills of teachers. Landsberg (2005:61) quotes Scruggs and Mastropieri in stating that for inclusive teaching to work, teachers need logical and intensive training, either as part of initial training or as a well-planned in-service training by competent and knowledgeable people.

As key to successful implementation of an inclusive system, educators will need time, on-going support and inservice training, thus, change requires a long-term obligation to professional development (Swart,Engelbrecht, Eloff\&Pettepher2002:175). Prinsloo (2001:345) refers to the National Committee on Education Support Service document (DoE, 1997:12-19), wherein it is stated that the absence of on-going in-service training programmes leads to anxieties, uncertainties, low self-esteem and lack of innovative practices, which in turn impact on the attitudes of teachers. Swart 
(2002) argue that teachers are competent but because of lack of understanding of inclusive education many fail to understand its essence. One cannot implement something about which one is ignorant.

James (2000) states that staff members need to have access to three major phases of professional development: initial training, professional induction, and in-service and post-service training. For many teachers, however, the content of the training remains abstract and unrelated to the nature of the teaching job and the conditions in which they work. Inclusive initial teacher education requires methods that are themselves inclusive. Nel (2007) states that the demands on the teaching profession are evolving rapidly, requiring teachers to reflect on their own learning requirements in the context of their particular school environment and to take greater responsibility for their lifelong learning. Avramidis (2010) concurs with Nel, stating that without a coherent plan for teacher training in educational needs of children with Special Education Needs (SEN), attempts to include them in the mainstream will be difficult.

UNESCO (2004) suggests the following strategies that can help in the implementation of inclusive education:

$>$ Identifying support available in the school

$>$ Identifying support available in the vicinity around the school

$>$ Identifying barriers to learning in class

$>$ Identifying barriers to learning in the broader school environment.

\subsection{Support for teachers in implementing Inclusive Education}

Reid (2010) states that a fully inclusive educational setting necessitates planning, trained teachers and other support staff. Inclusive classrooms and the elevated expectations for all students have a profound impact on pre-service teacher preparation (Michael\&Reid2010). Reynolds and Fletcher (2007:346) argue that teachers need certain skills and knowledge that will help them teach children with special needs, so they need to know what they should do in order to enhance the learning process. Teachers maintain that, if the aim of inclusive education is to be successful, support systems must be available. If teachers attend regular workshops, read journals, books and other sources and the technological advancement available in the field of special education they can familiarise themselves with it and this will go a long way in stimulating the learning process (Smith, 2010). Moreover, Smith (2010) explains that teachers can also help students with special needs adapt to the mainstream classroom environment through equipping themselves with necessary technology available. Muthukrishna (2002:16) maintains that if support systems in school were to focus on supporting teachers instead of addressing barriers to learning and development the learners would benefit. Cardona (2009:35) notes that focus on initial teacher education would provide the best means to create a new generation of teachers who will safeguard the successful implementation of inclusive policies and practices.

Opertti (2009) states that teachers should be equipped with the appropriate skills and materials to teach diverse students and meet the diverse needs of all different categories of learners. Moreover, there is a need to develop a common sense of purpose amongst teachers which may require a paradigm shift in their mind set about schools and their pedagogies, re-examining the practice to make them more tolerable, flexible and responsive.. Heiman (2001:46) believes that systematic training and intensive preparation would improve teachers' attitudes to inclusion Avramidis (2010) states that support from specialists is an important factor in shaping positive teacher attitudes to inclusion. Cook (2004:317) concurs with Avramidis, claiming it is possible that the combined effect between variables such as resources, parental support, larger budgets and greater availability of special service personnel would contribute to improved attitudes in teachers.

Strategies for developing an inclusive system of support have to include a focus on collaborative support, for example the development of School-Based Support Teams (SBST) the establishment of district support teams, employment of educational psychologists and school counsellors, and building of special schools as resource centres. South Africa"s Education White Paper 6 on inclusive education (DoE, 2001) encourages the involvement of all support professionals to increase their involvement in multiple areas and levels of support, for example, at district and school levels. Nel (2002), in his paper argues that teachers need to have a common goal, conceptual framework and language, as well as a set of instructional and technical skills to work with the diverse needs of learners. Nel (2000) further argues that teachers need training, as most are unfamiliar with how to support learners with barriers to learning and are thus unable to respond appropriately to the diverse needs of inclusive education.

\subsection{Identification of learners with barriers to learning}

According to Nel (2011),learners with barriers to learning refers to a group of learners with physical, sensory, intellectual or various barriers requiring specialised apparatus or teaching support in order to give them access to the curriculum and 
to allow them to participate effectively in the learning process. The process of identification is one of the teachers" tasks and it is very important for them to identify the learners early, and this also increases the possibility of rectifying or improving the situation, For Dutoit (2004:180), identification issues have been a difficult topic since the origins of the concept of learning difficulties. The heart of the construct, however, has been the notion of „unexpected underachievement". The person with learning difficulties has been conceptualised as a person who is unable to learn adequately under circumstances that should support positive outcomes. Thus, learning difficulties have been traditionally identified with a person who underachieves despite an absence of other conditions associated with it.

Dutoit (2004) suggests observation as the basic skill which teachers should master in order to identify learners with barriers to learning successfully. They define observation as the process of deliberately observing and listening to a learner in order to gain more information on possible barriers to learning. Salvia and Ysseldyke (1995:98) state that teachers should have no preconceived ideas when they begin to observe and describe any behaviour which comes to their attention. By closely observing children"s conduct in the classroom, on the sports field, during other extramural activities and on informal occasions such as school functions, one can determine whether their conduct is indicative of any deviant behaviour. For Dutoit (2004:185), it is also important to observe learners in the learning situation.

Dutoit (1997:185) suggests the following as indicators of learning and behavioural problems:

$>$ Homework which is either incomplete or not done at all

$>$ Written assignments that are of poor quality and invariably submitted late

$>$ Books that are habitually lost or left at home

$>$ Fearfulness

$>$ A lack of friends

$>$ A preference for remaining in the classroom during break (recesses)

$>$ A sudden change in physical appearance

$>$ Drowsiness and lack of interest in the lesson presentation.

Weeks (2000:17-21) describes the various barriers to successful learning as:

> Permanent shortcomings in a person"s make-up. These shortcomings include:

$>$ Sensory disabilities which occur if one of the five senses is affected, that is, sense of sight, smell, taste, hearing and sense of touch.

$>$ A physical disability is when a person"s external physical functioning is affected, for example, a person can have a crippled arm.

$>$ Intellectual disability renders the affected person less capable than the average and as a result he or she finds it more difficult to comprehend and to learn. In the case of multiple disabilities, the person suffers more than one disability.

$>$ Developmental problems

These could manifest as a total delay in all or most of the developmental areas, for instance, when a child"s development does not correspond more or less with that of other children in the same age group or not being school ready at the accepted age for new candidates. Another example can be of a two year old who cannot even say a few words.

\section{$>$ Learning problems}

Learners are said to have learning problems when they find it difficult to master learning tasks which other learners in class can master. The learning is such that learners have many challenges, more especially when teachers do not support them. For their learning to be effective they need much support and patience from their teachers. The teacher has to identify that the learner has learning problems then support the learner in a way that suits that learner. According to Weeks (2000:17-21) the concept "disadvantaged learners" refers to those learners whose education has fallen behind as a result of social, economic or political circumstances.

$>$ - Circumstantial problems

These could prevent learners from having a fair chance to make a success of their school career .One example of socio-economic status can be a learner who is a victim of HIVIAIDS. Such learners come from child-headed families or are themselves heading the family. Due to these problems, the learner is disadvantaged and cannot learn effectively even if that learner has the potential to learn. Some learners are low achieving learners, no matter how hard they do not succeed. It can be stated here that once the learner has shown signs of learning barriers it is important to carry out an assessment as a way towards addressing them. 


\section{Methodology}

The qualitative method as a mode of inquiry was used to get more information on the ways in which teachers are supported to implement inclusive education in schools. The research design used was a case study, and defined as a detailed examination of something. McMillan and Schumacher (2006:398) state that in a case study design data analysis focuses on one phenomenon which the researcher selects to understand in depth, regardless of the number of sites or participants. It suited this study because the researcher focused on what is happening in one school in depth.

I conducted this case study at one primary school, a pilot school for inclusive education, located in the Manzini Region in Kwaluseni. I chose it because it was different from the other government schools. Most of the learners in the school are from within Kwaluseni and neighbouring areas.

I used purposeful sampling, which is selecting information-rich cases for study in depth. McMillan and Schumacher (2006:401) argue that purposeful sampling is used to increase the utility of information obtained from a small sample. Moreover, it is based on the judgment of the researcher, in that a sample is composed of elements that contain the characteristics that are most representative of typical attributes of the population (De Vos, Strydom, Fouche\& Delport 2005:202). Ten teachers were selected, five males and five females. Their age group ranged between, 30 and 45 . These teachers were selected because they had all undergone training, their teaching experiences varied (some were fresh from college whilst others had been teaching for some time), and they represented all the grades in the school.

Data was collected through in-depth individual interviews during the teachers' free time, and through document analysis, including learners' work (class work, tests, school reports), and school rules and regulations. Through this strategy I was able to get detailed research reports on the ways in which teachers are supported to implement inclusive education.

\section{Findings and Discussion}

\subsection{Lack of clear or precise knowledge or understanding of what constitutes Inclusive Education}

The study revealed that teachers lack a clear knowledge and understanding of what precisely constitutes inclusive education. South Africa"s Education White Paper 6 (2001:6-7) as stated in the previous section, defines inclusive education as acknowledging that all children and youth can learn and that all need support. It continues to state that inclusive education is about changing attitudes, behaviour, teaching methodologies, curricula and the environment to meet the needs of all learners. However, teachers have a diverse understanding of inclusive education, defining it in different ways. One teacher said, "... inclusive education is when in class you have to teach learners who have different abilities and many learning difficulties." Another said "Inclusive education is being aware of children who have problems academically." A third said "Inclusive education involves bringing together pupils in one class of different physical differences." A fourth said "Inclusive education is the cluster or bringing of kids from different environment so that all these kids may end up knowing better about education is not necessarily trying to put them according to their capabilities it's just a cluster of kids from different environments". From these examples it is evident that teachers lack a precise knowledge of what inclusive education is. Contrary to the kingdom of Swaziland"s national response to psychological needs of children (2010:25), which defines inclusive education as a policy approach that includes and meets the needs of all learners, enabling schools to serve and welcome all learners and is rooted in the basic human right, the learners have yet to be accommodated, regardless of their needs.

From the teachers" definitions it is also evident that teachers lack the knowledge that learners need to be supported for them to learn so that learning is of value to every learner. As Dutoit (2004:3) argued, the term implies that education should be of value to all learners, meeting the educational needs of all, even though they differ from those of others. Teachers in their responses supported this argument, in that they mentioned that learners" needs in a class were different, with some saying that inclusive education involved bringing together learners in one class of different physical differences, whether disabled or not. Teachers are not aware that inclusive education also involves changing teaching methods so as to cater for the needs of all learners.

One teacher defined inclusive education as a discipline which accommodates different learners with different capabilities in class, thus supporting UNESCO"s (2009) stipulation that inclusive education is a process of addressing and responding to the diverse needs of all learners, youth and adults, through increasing participation in learning, cultures and communities, and reducing and eliminating exclusion within and from education. Teachers are not aware, from the evidence of this study, that inclusive education is about change in the way outlined by the Enabling Education Network (2012), that is, as a constantly evolving process of change and improvement within schools and the wider education 
system to make education more welcoming, learner friendly and beneficial for a wider range of people.

At least teachers know that learners should not be discriminated against, and if they are not then, as one teacher said, it is education whereby one includes all situations that are found in the school. If one is physically disabled, a slow learner or a fast learner, one is still included in the education. If there is no discrimination of learners the classroom might be friendly to all but this does not guarantee that the learners are not excluded. Because they cannot be discriminated against they may still be excluded from the teaching and learning.

For inclusive education to conform to the ideals cited by UNESCO (2005), a process is required to respond to learners" diversity by increasing their participation and reducing exclusion within and from education, focusing on those who, due to differing reasons, are excluded or at risk of being marginalised.

\subsection{Lack of exposure and training in Inclusive Education}

This research has revealed that the majority of the interviewed teachers had not been trained in inclusive education whilst undergoing their initial teacher training, which explains their lack of clear and precise knowledge and understanding of what inclusive education is. Swart et al. (2002) argue that many teachers are competent but because of lack of understanding of inclusive education, many fail to understand its essence. One teacher said: "I was not taught about this but the little that I knew I got from some teachers who had attended workshops on inclusive education". Another said: "I have not been trained but have asked people what "inclusive" means and they have explain the meaning of it."

Teachers who had trained in inclusive education were currently furthering their studies, but during their initial training they had not been taught it. Teachers now have to implement inclusive education, so they have realised that there is a need for them to be trained. Since they learn about inclusive education informally that will also result in other problems, as they develop different understanding which may not be related. Landsberg (2005:61) quotes Scruggs and Mastropieri,,s view that for inclusive teaching to succeed, teachers need logical and intensive training either as part of initial training or as a well-planned in-service training by competent and knowledgeable people. Inclusive initial teacher education requires methods that are themselves inclusive. Avramidis (2010) concurs with Nel who writes that without a coherent plan for teacher training the attempts to include these children with Special Education Needs in the mainstream will be difficult On a different note, Nguyet (2010) suggests that countries with a long-term goal of implementing inclusive education should ideally have it as a compulsory subject for all teacher candidates and an integral part of the teacher training curriculum.

\subsection{Inability to identify learners with learning difficulties}

The study revealed that teachers are unable to identify learners with learning difficulties. One teacher said that, "...it becomes difficult to teach because sometimes you end up beating the child not knowing thinking that the child will change yet you are not solving the problem of the child." This may be because the teachers fail to identify the learners" problems so in turn cannot provide the necessary support. This confirms Dutoit"s (2004:180) claim that identification issues have been a difficult topic since the origins of the concept of learning difficulties. The person with learning difficulties has traditionally been conceptualised as a person who is unable to learn adequately under circumstances that should support positive outcomes. Thus, learning difficulties have been identified with a person who underachieves despite an absence of other associated conditions. Teachers need to know how to identify learners with barriers to learning, and that is crucial if the learners are not to drop out of schools because of the endless punishment they receive from their teachers.

Dutoit (2004:185) suggest observation as a basic skill which teachers should master in order to identify learners with barriers to learning successfully, so that they can give the necessary support. The most important problem that has to be overcome in this process is the training and empowerment of teachers to identify and effectively support learners who experience barriers to learning, as teachers feel themselves inadequate in person and in training to deal with so much diversity amongst the large number of learners in their classrooms.

\subsection{Teachers unsure on who should implement Inclusive Education}

Teachers are unsure as to who should implement inclusive education, as they gave responses such as " our government should do something about this inclusive education because teachers like myself in my college. I was not taught about inclusive education and now in class it's so difficult to accommodate everyone because of the child who has this problem." Another teacher said that "... government has to play her part in implementing it at tertiary level and also the teacher in the class." Another teacher said " must start with the ministry of education by educating teachers and then at 
schools, the principals must be supportive of inclusive education, it should start with the government then move down to all the stakeholders in the teaching fraternity." For another, "Teachers themselves have to implement inclusive education because they are in class where the learners are found. I am not sure whether the government or the teacher should implement."

The Swaziland National census of 2007 indicates that the number of people living with disabilities is now $17 \%$ of the total population, compared to $3 \%$ in 1997. I argue that the absence of policies is delaying the implementation of inclusive education and in the process many learners are classified as underachievers in school. South Africa"s Education White Paper 6 has policies as far as inclusive education is concerned, and it serves as a guideline for both the teachers and the government on implementation. It is therefore recommended that Swaziland have an inclusive education policy made available for the schools to use.

\subsection{Teachers are not supported in the implementation of Inclusive Education}

The findings indicated that teachers are not supported in the implementation of inclusive education, either by the principal or the DoE. One teacher said, "There is no support at all, maybe if it can start from the top, our principal must be wellversed on inclusive education." Another teacher said "The administration in my school is not supportive." Jayne Piuik,Beutel\&Jose. (2010) argue that a successful inclusive school climate depends on the attitudes and actions of the principal, a supportive school community and shared values and language, a view echoed by one teacher, "The principal must change his attitude for the implementation to be successful." Swart (2002:178) state that the attitudes towards inclusive education and learners with barriers to learning contribute to ineffective implementation of inclusive education in classrooms, because as it is the principal can stand in the way of these teachers. Furthermore, Smith (2010) states that however teachers try to implement some of the strategies, if they lack support from the administrators then very little can be achieved.

Teachers believe that the support of the principal and other school leaders is critical for them to implement inclusive practices, a view supported by Daane (2000) and Hammond and Ingalls (2003). The principal and school administration is part of the staff and cannot exclude teachers in what they are doing within the school. Teachers do attend workshops but not for inclusive education. The workshops are for the other subjects and only a few have access to those on inclusive education. The lack of the workshops is a problem, as referred to by Prinsloo (2001:345) in connection with the National Committee on Education Support Service Document (DoE, 1997:12-19), wherein it is stated that the absence of ongoing in-service training programmes leads to anxieties, uncertainties, low self-esteem and lack of innovative practices, in turn impacting on the attitudes of teachers.

Teachers maintain that if the aim of inclusive education is to be successful, support systems must be available. If they attend regular workshops, read journals, books and other sources, and use the technology available in the field of special education, they can familiarise themselves with it and go a long way in stimulating the learning process, as argued by Smith (2010). As a result of the absence of support, especially the training and support from qualified personnel, such as speech and hearing therapists and psychologists, to name a few, teachers are not sure of what to do as a way of teaching these learners. As key to successful implementation of an inclusive system, educators will need time, on-going support and in-service training. Thus, change requires a long-term recommend that support systems be made available and on-going for the implementation of inclusive education to be successful. Commitment to professional development (Swart 2002:175).

\section{Conclusion}

Teachers are integral to the implementation of inclusive education (Haskell, 2000), but that is not possible if they lack the necessary knowledge and skills. From their responses, teachers have realised the importance of inclusive education and they are aware that they are the ones to implement it. Research communicates shows that teachers are the key to the success of inclusionary programmes (Cant, 1994), as they are viewed as cornerstones in the process of including learners with disabilities in regular classes. Even though teachers are ready, the evidence shows that they lack certain skills. As argued by Reynolds and Fletcher (2007:346), there are certain skills and types of knowledge that will help teachers teach children with special needs. Smith (2010) states that teacher training in these areas improves participation and accommodation efforts as well as teacher confidence. If the teachers could receive the training their participation would be improved as they would be ready to implement inclusive education. The aim of this paper was to find strategies that can be used to support teachers to implement inclusive education. From the findings, I would suggest the following:

$>$ Government must provide and finance in-service training for teachers, as this can empower teachers and 
change their attitude towards inclusive education.

$>$ Support systems must be made available and on-going for the implementation of inclusive education to be successful.

$>$ Teachers must first know what inclusive education is before they start to implement it. This means that they must be exposed to inclusive education through formal training, that is, during their initial teacher training.

$>$ People competent and knowledgeable in inclusive education must be hired so that they provide teachers with logical and intensive training. Such experts could train teachers during their initial training and during inservice programme.

$>$ Teachers must be equipped with the relevant knowledge on inclusive education before encountering it in class.

> The education system must review its policies so that they accommodate inclusive education. The accommodation must be there in reality and not in theory. The education system must be flexible for change because accommodating inclusive education will come with some new challenges which the Department must be flexible in facing and willing to address, instead of being resistant.

\section{References}

Agran,Alper \& Wehmeyer.(2002).Access to the general curriculum for students with significant disabilities :What it means for teachers .University of Rocher, N.Y.

Anderson, G. (1990). Fundamentals of educational research. London: Palmer press.

Avramidis ,E.\& Norwich, B. (2002).Teacher's attitudes towards integration/ inclusion: a review of literature. European Journal of Special Needs Education. http//dx.doi.org/10.1080/0885625.

Cameron,C.(2004)Supporting teachers:A foundation for advancing inclusive education, Toronto, Ont,"linstitut, Roeher institute

Cant, H. (1994). Inclusive education. The Alberta Experience. Practising Administrator, 16(3), 38-41.

Cardona, C.M(.2009).Teacher education. Students" belief in inclusion and perceived competence to teach students with disabilities in Spain. Journal of the International Association of Special Education.10 (1) 33-41

Cohen, L. \& Manion.(1994). Research methods in education, 4th edition, New York: Routledge.

Constitution of Swaziland. 2005.Websters Print ,Mbabane

Cook, B.(2004). Inclusive Teachers' Attitudes towards Their Students with Disabilities: A replication and extension. The Elementary School Journal, University of Chicago,104(4):307-320.

Culatta,T \&Warts.(2000).Fundamentals of special education .New York, Routledge

Daan, (2000).Understanding educator attitudes towards implementation of inclusive education.www.dsq-sds.org

Department of Education (DoE).1996. South African Schools Act, No 84 of 1996. Pretoria: Government Printer.

Department of Education.(2001). White Paper 6 on special needs education: Building an inclusive education and training system. Pretoria. Government printers.

Deputy Prime Ministers office Policy document.(2010).UN convention on the rights of children .Mbabane ,Swaziland.

De Vos,A.S.(2001).Research at grassroot.Van Shaik publishers. Pretoria

Dutoit, L .2004.Education for all. Pretoria. University of South Africa

Engelbrecht, P, Oswald, M, Swart, E \& Eloff, I.(2003). Including learners with intellectual disabilities: stressful for teachers? International Journal of Disability, Development and Education, 50(3):293-307

Eraclides ,G \& Achia ,V.(2008).Teacher's needs in supporting students with disability in the classroom. A research report.

Hammonds \&Ingalls.(2003).Teachers attitudes towards students with disabilities in Haitai.www.internationalsped.com

Haskell, D. H. (2000). Building bridges between Science and Special Education. Electronic Journal of Science Education., 4(3).

Heiman, T. (2001). Inclusive Schooling - Middle School Teachers' Perceptions. School Psychology International, 22(4), 451-462

James,L.(2000).Thematic studies, inclusion in education :The participation of disabled learners. Coordinated by UNESCO

Landsberg, E.(2005).Addressing Barriers to Learning. A South African Perspective. Pretoria: Van Schaik.

Mcmillan ,J.H\&Schumacher,S.(2001).Research in education: A conceptual introduction. 5th ed. New York: Longman.

Mcmillan J.H. \&Schumacher,S.(2006). Research in education: Evidence based enquiry.6th ed. Allyn and Bacon, Boston.

Merriam,(1998).Qualitative research and case study applications in education .San fransisco: Jossey-bass publishers

Muthukrishna, N.(2001). Changing roles for schools and communities. In P. Engelbrecht \& L Green (Eds.) Promoting learner development. Pretoria: Van Schaik

National response to psychosocial needs of children, 2010: Policy \# 3 draft 3.Webster print ,Mbabane

$\mathrm{Nel}, \mathrm{M} .(2007)$. The training needs of South African in-service teachers regarding the support of learners experiencing barriers to learning. Paper presented at the AARE conference at Notre Dame University, Fremantle, Australia.

Nel,N.(2011).Support services within inclusive education in Gauteng: The necessity and efficiency of support. Mevlana international journal of education, vol. 1, pp.38-53,30 August 2011

Nguyet, D. \& Thuha.A.(2010).Preparing teachers for inclusive education. Crs Vietnam

Opertti,O(2009).Teacher education for inclusion. Project kick off meeting. Dublin, Ireland 
Piuik J. (2002). Barriers and facilitators to inclusive education: Exceptional children. Volume 69

Polkinghorne D.E.(1995).Narrative configuration of qualitative analysis .International journal of qualitative studies

Prinsloo, E.(2001) Working towards inclusive education in South African classrooms. South African Journal of Education, 21 (4):344-348.

Reid D.(1996).Qualitative research analysis types and software tools.New York:Failmer

Reynolds C.(2007).Encyclopedia of special education. London Wiley p.346

Salvia, J. \& Ysseldyke, J. E. (1995). Assessment. Boston: Houghton Mifflin

Scruggs, T. E., \& Mastropieri, M. A. (1996). Teacher Perceptions of Mainstreaming/lnclusion, 1958-1995: A Research Synthesis. Exceptional Children, 63(1), 59-74

Smith, C.(2010). Inclusive education in U.K

Swart, E; Engelbrecht, P; Eloff, I \& Pettipher, R.(2002).Implementing inclusive education in South Africa: teachers' attitudes and experiences. Acta Academica, 34(1): 175-189.

Talmor ,Reiter \& Feigin .(1990). Remedial and special education. Sage publication

UNESCO.(2005). Guidelines for inclusion. Ensuring access to education for all, Paris

UNESCO.(2009).Policy guidelines on inclusion in education.7place de Fontenoy,Paris,France.

Weeks, F. 2000. Behaviour problems in the classroom: a model for teachers to assist learners with unmet emotional needs. DEd thesis. Pretoria: UNISA. 